Dialectologia 27 (2021), 49-70.

ISSN: 2013-2247

Received 19 May 2019.

Accepted 19 October 2019.

DOI: 10.1344/Dialectologia2021.27.3

\title{
A BRIEF INTRODUCTION TO KHORASANI TURKISH IN IRAN ${ }^{1}$
}

\author{
Behnam BEHFOROUZ \\ International College of Engineering and Management, Oman * \\ behnam@icem.edu.om
}

\section{Abstract}

The present study is just for the purpose of raising the awareness of language endangerment for Turkish language of Khorasan area in Iran, especially the Turkish accent in Joghatay (a city which is located in Khorasan Razavi province in Iran). Reasons like immigration, being a minority, and social prestigious behavior makes this accent under the risk of extinction.

\section{Keywords}

language, endangered languages, Khorasan, Turkish, Joghatay

\section{UNA BREVE INTRODUCCIÓN AL KHORASANI TURCO EN IRÁN}

\section{Resumen}

El presente estudio tiene como único objetivo crear conciencia sobre la amenaza que se cierne en el idioma turco del área de Khorasan en Irán, especialmente el acento turco en Joghatay (una ciudad de la provincia de Khorasan Razavi en Irán). Causas como la inmigración, ser una variedad minoritaria y el prestigio social provocan que este acento esté en peligro de extinción.

\footnotetext{
${ }^{1}$ I would like to use this space to appreciate three people wholeheartedly for their endless support and motivation to do this short research. First of all, my father, Mr. Aliakbar Behforouz, then Mr. Aliakbar Joghataee (Rahim), who introduced a very valuable book plus fruitful history of Turkish language, and finally Mr. Jalal Gholizade Mozreji, whose research in the field of Turkish accentology and dialectology are very famous in Iran, also his permission to use parts of his book is highly appreciable.

* Oman, Muscat, 111 Seeb Street, International College of Engineering and Management, Foundation Department.
} 


\section{Palabras clave}

language, lenguas amenazadas, Khorasan, turco, Joghatay

\section{Introduction}

Number of languages are more than the number of countries in the world. The statistics shows more than six thousand languages (Maffi 1999, Gordon 2005) while the number of nations reached only 192 (UN 2007). Half of the population of the world is talking 12 most spoken languages, while the other half rest of the other languages (Nettle \& Romaine 2000). Because of the increase in the number of widely used languages daily, the other languages are disappearing, and this is because the speakers are shifting to the majority languages (Maffi 1999, Tsunoda 2001, Crystal 2000). The horrible issue is that by the end of $21^{\text {st }}$ century, half of these languages will be disappeared. Crystal (2000) estimated that in about every two weeks a language will die in a corner of the world.

\section{Endangered language}

Language extinction is a very important dilemma that linguists and language planners paid a very special attention over decades. Speakers of many languages which have smaller dominance, stop to use their heritage, because of various reasons, and change to use another language. Initially, parents might use the second language with their children but slowly, the intergeneration transfer of the native language shortens or finally disappears. The result of this action is the reduction of speakers of the heritage language and simultaneously the language fades and is not in use anymore. Languages which have not been documented sufficiently, disappears over the time (Lewis, Simons \& Fennig 2015).

Language endangerment may be a degree related matter. One side of this scale includes languages which are strong and probably vast in the matter, size of the speakers or practical usage, but these languages never practiced being under the colony of a 
dominant language. In the other side of this scale, there are some languages in the border of death or extinction. They are losing their speakers who are looking for the relation of the language and their identities. There are some degrees lesser or bigger in between (Lewis, Simons \& Fennig 2015).

Two divisions can be source of endangerment characterization. The first one is the number of the speakers who are identified by a special language and the other one is related to the functions of language, for which this language is being employed. When the population of a language become fewer and fewer, they are not speaking the language anymore, and they are not transferring the language to the new generation, a language might be engendered. Less usage of a language in daily life can be another sign of language endangerment because the language will gradually lose its social and communicative features (Lewis, Simons \& Fennig 2015).

The initial and maybe the important factors in language endangerment are those which stimulate the speakers of a language to quit communicating through it and then socio-psychological barriers of language death for the former speakers of that language. Since there is a relation between language and culture, thus the extinction of a language means social and cultural disturbance. Generally speaking, the heritage of the human society shrinks along with language disappearance (Lewis, Simons \& Fennig 2015).

According to Ethnologue website, the following factors are among those which are functional for language endangerment assessment:

1. The speaker population

2. The ethnic population; the number of those who connect their ethnic identity with the language (whether or not they speak the language)

3. The stability of and trends in that population size

4. Residency and migration patterns of speakers

5. The use of second languages

6. The use of the language by others as a second language

7. Language attitudes within the community

8. The age range of the speakers

9. The domains of use of the language 
10. Official recognition of languages within the nation or region

11. Means of transmission (whether children are learning the language at home or being taught the language in schools)

12. Non-linguistic factors such as economic opportunity or the lack thereof. "

A language is also endangered when the number of the speakers are reducing and the last group of the speakers (generation) don't exercise the language even passively (Tsunoda 2001). An active and healthy language can be disappeared in different stages. It used in daily life and then transferred generation to generation until reached to an extinction destination (Jongbloed 2007).

The word extinct is typically used to explain a type of language which has no any other speaker. Leonard (2008) challenged the function of this word. He believes that the word extinct, surely, refers to a sort of biological species which are at the risk of extinction. Biology considers a species the extinct one if there are no living creatures of that type. If a creature of some kind extinct, then there is no single chance for returning or resurrection. Leonard in 2008 refers to the previous statement, and believes that, this cannot be true for languages. He used the noun phrase of "sleeping languages", that is, languages which are not famous at the moment, but they are documented, and as a heritage, they might be used again. Sleeping languages can be returning back to awaken situations if any person of human in the world relearns the language from those documentations, like Leonard's Miami Community (Hoffman 2009).

If a language is easy to use, to run a business and as a tool for communication like English, Dutch, Spanish and Italian, then it will be revealed that younger generations are not using that language, and since they are not educated in that language and the number of speakers of that language is small, the language is gradually going to die (Malone 2019). Languages with few numbers of speakers are considered as endangered languages. Categorizing the languages can be done in two ways:

1. Safe languages: they are official languages of the government and the number of speakers is at least 100000 . 
2. Endangered languages: type of languages that have been learnt by children before and the younger generation won's learn them anymore (Isa, Ahmed \& Grema 2014).

There are various reasons why a language changes to be endangered. Some of them are as follow

- the death of its speakers due to natural disasters, diseases, genocide and etc.

- language communities' disintegrations. It can be happened because of displacement or assimilation to the bigger or dominant population, and even economic concerns.

- The media effect. It will cause some homogenization effect like the dominant language television, radio and print media.

And finally, the forced leave of the language (Hoffman 2009).

\section{Dead language}

A language is called "dead language" when it is not spoken by any persons as the main channel of the communication, or they are not learned by speakers as the native language of that society, for instance Latin. Death of the last speaker of a language will lead to death of that language. This is not always the story, because the last speaker of the language doesn't have any friend or partner to talk the language regularly, thus, the language is extinct or sounds dead (Isa, Ahmed \& Grema 2014).

\section{Turkish language - in the universe}

In terms of origin, the Turkic language is among the group of Ural-Altaic languages and more correctly, it is Altaic and is referred to the set of languages whose peoples have 
moved from the region between the Ural-Altaic Mountains and migrated to other regions throughout history.

The word Altaic is a Turkish word that means Altin Daghlari (Golden Mountains) and the Altaic languages include: Turkish, Mongolian, Tunquz, Korean and Japanese languages.

This group of languages grammatically are agglutinative and they have suffix, so that in these languages, by adding different suffixes to words, different words come in accordance with certain meanings without modification of the origin and root of the words.

In this group of languages, unlike Indo-European languages Group, the word root is fixed and does not change at time of inflection.

The most important reasons for the differences between Altaic and Indo - European languages:

1. The first one is the grammatical structure and the integration of words within the sentence.

2. The language's attribute of being agglutinative and having suffix.

3. The existence of the rule of harmony of sounds.

The Turkish language, is considering method and grammar, is one of the most methodical languages in the world and considering the number of verbs and other points of linguistics is one of the richest languages.

In general, the history of the Turkish language is as follow:

1) Altaic age: the Age of Formation, which according to the studies, in this era, Turkish and Mongolian formed a common language and did not differ much.

According to famous linguists like Jerar Closen, the common words in two languages are words interred by Turkish language into Mongolian language.

2) Pro-Turk era: available Turkic language in the $B C$ era.

3) Early Turkish era: including the Turkish language from the first century AD to the fifth century AD (to the establishment of Gokturk Kingdom in Mongolia).

4) Old Turkic era: Turkish language from the 6th century $A D$ to 10th century $A D$ (including the region era of Gokturk and the Uighurs). 
5) Middle Turkish language era: the existing Turkic language from the 10th century CE onwards till the 16th century CE; it comprises a common Turkic in the region of Central and Eastern Asia with the Western region.

In this period, important governments have been established by the Turks such as Kara Kaniyan, Ghaznavids, Seljuqs, Kharazmshahian, Timurids (Mughal Empire) and etc. (Mozregi 2012)

\subsection{Modern Turkish Era}

Since the $16^{\text {th }}$ century, new divisions in the Turkish language have been starting, based on the accents and the various regions where the Turkish language is spoken.

In this period, until the middle of the $20^{\text {th }}$ century, important governments have been developed by the Turks such as Afsharids, Safavids, Ottoman, etc.

Now with regard to the geography of Turkic-speaking regions which centrally begin from west of china (East Turkestan or Xinjiang) and countries like south of Russia, some parts of Mongolia and Kazakhstan, Kyrgyzstan, Turkmenistan, Uzbekistan, Iran, Azerbaijan, Turkey, Cyprus scattered across the other countries in Asia such as Syria, Iraq and even European countries such as Greece, Albania, Bulgaria and Germany ; superficial differences with respect to the geographic circumstances and adjacency with other languages are raised and until now so many division were made according to different bases.

Therefore, the Turkish language is divided into the following regional groups according to Professor Farhad Zeynalof - Turkish linguist Professor in Azerbaijan -

1. The Oghuz group includes Turkic languages existing within nations of Turkey, Azerbaijan, Iran, Turkmen, Qaqawooz and Tatars of Crimea.

2. The Kipchaks Group includes Turkic languages existing within nations of Kazakh, Kyrgyz, Karakalpakstan, Altaic and Nogai.

3. The Bulgar group: includes Turkic languages existing within nations of Tatar, Kazan, Bashgerd, Karachai, Balkar, Kumyk, Koraeim. 
4. Qarloq group, Uyghur: Turkic languages existing within nations of Uzbek, Yeni Uyghur, Sari Uyghur and Salaar.

5. Uyghur group, Oghuz: includes Turkic languages existing within nations of Tuva, Kara Karsh, Khakas, Shoor, Barabin, Koyerick.

6. Chuvash.

7. Yaqut.

Following, is a brief, useful explanation of important regions where Turks are living in them with respect to this division:

1) The Oghuz Group: is the most important Turkish group that the great and important empires like Seljuqs and Ottomans raised from them which played a very important role in Islam and the region under their command.

Oghuz people (Ghez people) are the ancestors of the Turks of Anatolia, Azerbaijan, Iran, and Turkmen and currently, the majority of the speakers of Turkic language are from this group, divided into regions and following categories:

a) Istanbul Turkic (Ottoman Turkic): Turks in Turkey, the Balkans, Cyprus, and Turkish speakers in Greece, Yugoslavia, Romania, Bulgaria, Syria, Iraq, the southern regions of Crimea. Istanbul Turkic is the official language of Turkey and the northern part of Cyprus.

b) Azeri Turkic: Turks in Azerbaijan, Iran: east and west Azerbaijan, Ardabil, Zanjan, Qazvin, Hamada, the Qashqai people of Fars province, immigrated Turks in Tehran and so on, a group of Turks in Iraq, Turks of Khorasan (in the branch of Khorasan Turkic some of features of eastern group Turkic language: Chagatai, Uzbek, Turkmen (languages), and some of features of western group Turkic language: Azeri and Istanbul (languages) are seen. Azeri Turkic is the official language of Azerbaijan.

c) Turkmen Turkic: is the eastern accent of Oghuz group and is the official language of Turkmenistan country, the Turkmen of Iran and parts of Uzbekistan.

d) Gagauz: including the Turks of Ukraine, Moldova, East Romania and northeastern Bulgaria. 
2) Kipchaks group: Turkic speakers from this group are divided as follows:

a) Karakalpakians: they live in regions of Uzbekistan, Afghanistan, Xinjiang, China (East Turkestan).

b) Kyrgyz Turkic language: is the official language of Kyrgyzstan, as well as in regions of Uzbekistan, Kazakhstan, Mongolia, and China.

c) The Kazakh Turkic language: is the official language of the Kazakhstan, as well as in regions of Uzbekistan, Kyrgyzstan and Turkmenistan.

d) Altaic Turkic: The official language of the Republic is the autonomous Republic of Altai in Russia.

e) Noqai Turkic language: The official language of the States of Stavropol, Karachai and its people are located in Astrakhan, Krasnodar, and Dagestan.

3) Bulgar group: Turkic speakers from this group are divided as follows:

a) Kazan Turkic: The Turks located in the Ural-Volga regions (Tata, Bashgerd, Chuvash) and those who live in the republics of Tatarstan, Bashgerdstan and Chuvashia and their official language is Turkic.

b) Bashgerd Turkic language: The official language of the Republic of Bashgerdstan and some regions of the Republic of Tatarstan, Uzbekistan, Kazakhstan and Russia.

c) Kara chai-Balkar Turkish language: The Turkic language is created from an admixture of tribes (Oghuz, Kipchak, Bulgar) and they live in the autonomous provinces: Kara chai, Cherkessia, Kabarda-Balkar, and have official Turkish language.

d) Komok Turkic language: they live in the autonomous Republic of Dagestan and are created from an admixture of groups (Kipchak, Oghuz) and have official Turkish language.

e) Karaim Turkic language: these group of Turks are scattered in: Lithuania, Ukraine, and cities: Moscow, Leningrad, Crimea, and some parts of Poland and because of being in the minority in these regions, their official language is not Turkic. 
4) Qarloq - Uighur group: to mention the characteristics of the group's history, it needs to be said that the Uyghur group is the most civilized of the ancient Turks, who have played an important role in the cultural evolution of Central Asia with the establishment of the Uighur government in ancient times. These groups of Turks have had a special orthography of "Uighur Turkic" in the old days, which had been used for a long time in the various regions of old Turkestan to the end of the 15th century, and even the official orthography, and even the official orthography at the time of Mongol's domination was also "Uighur Turkic", and after that from the beginning of the sixteenth century onwards the Arabic orthography replaced (the Uighur orthography), now Latin orthography replaced the Arabic alphabet. Turkish speakers in this group are in different areas are divided into the following groups:

a) The Uzbek Turkic: is official language of Uzbekistan. The Uzbek, Turkic language is from eastern Turkic group (Joghataic), and has ancient literature in Turkish language and literature; the tribes of the existing Turks in north of Khorasan are of this group.

b) Sari Uighur Turkic: is the language of Turks in Kansu province in China, which is influenced by the Chinese and Mongolian languages; this branch of language is from the eastern Turkic group (Uighuric).

c) Yerni Uyghur Turkic: this group of Turks are located in the East Turkestan Region (Xinjiang Province) and in some parts of Uzbekistan, Kazakhstan and Turkmenistan, with the official Turkish language in the Xinjiang Republic in China.

d) Salaar Turkic: turks in some areas of China like: Siunxua, Te in Kay, Kanso. This branch of Turks came from a mixture of tribes (Oghuz, Kipchak) and in this type of Turkic, there are many entered Mongolian, Arabic and Chinese words.

5) Oghuz -Uighur group: this group of Turks comes from a mixture of tribes (Oghuz, Uighur) and include the following categories. 
a) Tuva Turkic: The Turks of Autonomous Republic of Tuva at the northwest of Mongolia belong to this group, and their official language is Turkic; some of Turks of this branch live in Krasnoyarsk and Mongolia.

b) Tufa Turkic: they live in former Soviet Union's Irkutsk region and in respect of branch they are from Tuva group and because of being in the minority in these regions, their official language is not Turkic.

c) Khakas Turkic: the Turks of Autonomous province of Khakas, belong to this and Turkish is their official language.

d) Shoor Turkic: these groups of Turks live in Kemerovo province at the Demircilerdeki area (the mountain of Blacksmiths) and their official language is Turkish.

e) Barabin Turkish: these group of Turks live in the Barabin region between the Irtysh and Om rivers.

f) Chulym Turkish (Koy rik): these group of Turks live around Chulym river (Tomsk province of Russian), and are in a dialect group with Shore and Khakas tribes.

6) Chuvash: they are the oldest of the Turkish tribes and live in the Republic of Chuvashia located in south of Ural- Volga area, and Turkish is their official language: some of them also live in area in the Tatarstan, Bashgerdstan and Russia.

7) Yakut: the group of Turks live in Sakha Republic, north of Siberia and Turkish is their official language, and are now part of Russia.

Note: At the moment, regardless of the Turkish language of Chuvash and Yakut nations, although they were separated from other Turk nations and their Turkish differs widely from other Turkish language groups, and the Turkish language differs widely from other groups, but the language segmentation of the rest of the Turk groups is understood by deliberation and precision for all Turks (Mozregi 2012). 
At the end of this discussion, we conclude that the Turkish language currently comprises 28 linguistic groups, that 20 of them have official scripts in their countries, which are summarized as follows:

1) Turkey's Turkish

2) Azeri Turkic (Azerbaijan and Iran)

3) Turkmen Turkic

4) Turkic of Tatars of Crimea

5) Gagauz

6) Qarachay

7) Balkar

8) Komok (Dagestan)

9) Noqai

10) Kazan

11) Bashgerd

12) Kazakh (Kazakhstan)

13) Kyrgyz (Kyrgyzstan)

14) Uzbek (Uzbekistan)

15) Karakalpak (Karakalpakstan)

16) Yeni Uighur

17) Sari Uighur

18) Altaic (Kamyk)

19) Khakas (Yenisei Turks)

20) Tuva

21) Shoor

22) Chulym (Koy rik)

23) Barabin

24) Salaar

25) Tufa (KaraKash)

26) Karaim

27) Chuvash

28) Yakut (Mozregi 2012) 


\subsection{Turkish language of Khorasan}

Turkic-language of Khorasan is the speaking language of almost 500.000 people from Khorasan who live mostly in northern of the province of Khorasan in the border zone of Turkmenistan, and parts of the central region of Khorasan (Mozregi 2012).

In the past, the linguistic group was part of the Turkmen branch, but with the research that was made in the last forty years $(1968,1973)$ from Turkology group of Göttingen University in, Germany, led by Professor Gerhard Durfer, the Turkish of Khorasan was agreed to be an independent accent of the Oghuz linguistic group branch. The most important areas with the Turk crowd in Khorasan are: Bojnord, Shirvan, Faruj, Quchan, Dargaz, Kalat, Esfarayen, Sabzevar, Neyshabour, Sarvelayat, Joveyn, Joghatai, Neqab, and immigrated Turks in Mashhad (from Khorasan, and Azeri). According to professor Durfer's researches, most of the Turks of Khorasan are from Oghuz group (the period of Seljuqi Empire). However, the arrival and migration of the Turks to Khorasan had begun since the Turkic-speaking reign of Ghazvanids and ended up till the end of Turkic-speaking reign of Safavids, but most of them entered the region during the dominance of Turkic-language reign of Seljuqis and, considering that the old Khorasan region was the gateway for tribes and other Turk groups to enter this area and other areas. Currently, the Turks in different areas of Khorasan are survivors of the groups of Turks from that time. Therefore, the Turkish language in the region with respect to the admixture of these Turk groups like Azeri, Joghataic, Uzbek, Turkmen and etc. has created a special accent in Oghuz Turkic group. Professor Durfer divides the Turkish language from Oghuz group into the four categories:

a. West - Western: Oghuz:

1) Istanbul Turkish (Ottoman)

2) Azeri Turkish

b. Eastern Oghuz:

3) Turkmen 
4) Khorasan Turkic (Mozregi 2012)

Durfer regards the Turkish language of Khorasan as a bridge and interface between the Turkish language in Turkey and Azerbaijan, but overall Khorasan Turkic is closer to Azeri Turkic and Turkey's Turkic rather than Turkmen Turkic, so that the Turks of Khorasan with a little care could be learned and understand Istanbul and Azeri Turkic language easily. According to Professor Durfer, Khorasan Turkish, is divided into 3 regional accents:

1) Western accent: Bojnord and its subordinated areas, Joveyn, Joghatai, Neqab and and etc.

2) Eastern accent: Shirvan, Faruj, Quchan, Dargaz, Kalat and subordinated areas.

3) Southern accent: Neyshabour, Sarvelayat and subordinated areas.

In spite of this division, there is very little difference of the dialects in this region and the three mentioned groups: the Eastern accent has a pervasive state due to its smooth fluency and the simplicity of the pronunciation of its words and also the large number of its speakers.

In the discussion of verbs at different grammatical times, Turkic is divided into two distinct groups:

1) For the western and southern regions (inflection of verbs in this group is similar to Azeri Turkic)

2) For the Eastern regions (inflection of verbs in this group is partly similar to Turkmen Turkic).

In the clear direction of this discussion, the inflection of a sample verb in Khorasan Turkic, according to the mentioned regions and comparing it to Azeri Turkish and their little differences-which is mostly in the pronunciation of suffixes, is mentioned (Mozregi 2012).

The inflection of the verb Içmāq 'drinking' in different tenses 
Dialectologia 27 (2021), 49-70.

ISSN: 2013-2247

\begin{tabular}{|l|l|l|l|l|l|}
\hline \multicolumn{1}{|c|}{ English } & \multicolumn{1}{|c|}{ Azeri Turkic } & \multicolumn{1}{c|}{ Sabzevar } & \multicolumn{1}{c|}{ Bojnord } & \multicolumn{1}{c|}{$\begin{array}{c}\text { Shirvan, } \\
\text { Quchan, Dargaz }\end{array}$} \\
\hline I drank & & İçdim & İçdim & İçdim & İçdim \\
\hline you drank & & İçdin & İçdeng & İçding & İçdin \\
\hline he/she drank & & İçdı & İçdı & İçdı & İçdı \\
\hline we drank & & İçdik & İçdik & İçdik & İçdik \\
\hline you drank & & İçdiz & İçdengz & İçdingz & İçdiz \\
\hline they drank & & İçdılar & İçdılan & İçdılan & İçdılan \\
\hline
\end{tabular}

Table 1. Simple past tense

\begin{tabular}{|l|l|l|l|l|}
\hline \multicolumn{1}{|c|}{ English } & \multicolumn{1}{|c|}{ Azeri Turkic } & \multicolumn{1}{|c|}{ Sabzevar } & \multicolumn{1}{c|}{ Bojnord } & \multicolumn{1}{c|}{$\begin{array}{c}\text { Shirvan, Quchan, } \\
\text { Dargaz }\end{array}$} \\
\hline I drink & Iç̧iram & İçiram & İçiyam & İçaman \\
\hline you drink & İçisan & Iç̧iray & İçiyang & İçasan \\
\hline He/she drink & İçir & Iç̧ir & İçi & İçadı \\
\hline we drink & İçiyiq & İçirag & İçiyiq & İçabiz \\
\hline You drink & İçisiz & İçirayz & İçiyingz & İçasiz \\
\hline They drink & İçirlar & İçilan & İçilan & İçadılan \\
\hline
\end{tabular}

Table 2. Simple present tense

\begin{tabular}{|l|l|l|l|l|}
\hline \multicolumn{1}{|c|}{ English } & \multicolumn{1}{|c|}{ Azeri Turkic } & \multicolumn{1}{|c|}{ Sabzevar } & \multicolumn{1}{c|}{ Bojnord } & \multicolumn{1}{c|}{$\begin{array}{c}\text { Shirvan, Quchan, } \\
\text { Dargaz }\end{array}$} \\
\hline I have drunk & İçmişam & İçibdıram & İçiddıram & İçibban \\
\hline you have drunk & İçişayn & İçibdırang & İçiddırang & İçibsan \\
\hline He/she has drunk & İçmişdı & İçibdı & İçiddı & İçibdı \\
\hline we have drunk & İçmişıq & İçibdırak & İçiddıray & İçibbiz \\
\hline You have drunk & İçmişayz & İçibdırangs & İçiddırangz & İçibsiz \\
\hline They have drunk & $\begin{array}{l}\text { İçibdılar/ } \\
\text { İçmişdılar }\end{array}$ & İçibdılan & İçiddılan & İçibdılan \\
\hline
\end{tabular}

Table 3. Present perfect tense

\begin{tabular}{|l|l|l|l|l|}
\hline \multicolumn{1}{|c|}{ English } & \multicolumn{1}{|c|}{ Azeri Turkic } & \multicolumn{1}{|c|}{ Sabzevar } & \multicolumn{1}{c|}{ Bojnord } & \multicolumn{1}{c|}{$\begin{array}{c}\text { Shirvan, Quchan, } \\
\text { Dargaz }\end{array}$} \\
\hline I will drink & İçacāğām & Ýççam & İçaram & İçarman \\
\hline you will drink & İçacāğsān & İççayn & İçarang & İçarsan \\
\hline He/she will drink & İçacāğdı & İçay & İçar & İçar \\
\hline we will drink & İçacāğıq & İççayg & İçaray & İçarbiz \\
\hline You will drink & İçacāğsiz & İççays & İçarangz & İçarsiz \\
\hline They will drink & İçacāğlār & İçallan & Ýçarlan & İçarlan \\
\hline
\end{tabular}

Table 4. Simple future tense 


\begin{tabular}{|l|l|l|l|l|}
\hline \multicolumn{1}{|c|}{ English } & \multicolumn{1}{|c|}{ Azeri Turkic } & \multicolumn{1}{|c|}{ Sabzevar } & \multicolumn{1}{c|}{ Bojnord } & \multicolumn{1}{c|}{$\begin{array}{l}\text { Shirvan, Quchan, } \\
\text { Dargaz }\end{array}$} \\
\hline I had drunk & Ýçmibdým & İçibdırdım & İçodum & Iç̧odum \\
\hline you had drunk & İçmişdın & İçibdırdın & İ̧̧odıng & İçodın \\
\hline He/she had drunk & İçmişdı & İçibdırdı & İçodı & İçodı \\
\hline we had drunk & İçmişdıq & İçibdırdık & İçodimiz & İçodık \\
\hline You had drunk & İçmişdız & İçibdırdız & İçodıngz & Ýçodýz \\
\hline They had drunk & İçmişdılar & İçibdırdılan & İçodılan & İçodılan \\
\hline
\end{tabular}

Table 5. Past perfect tense

Note 1. By adding the negative suffix "- $m$ " at the end of the main verb "Yç" all the mentioned verbs turn to negative ones.

Note 2 . The above examples are only brought to the familiarity of venerable readers around the very slight difference in spelling of verbs in different parts of Turkic-speaking regions which these differences are mostly in the pronouncing of suffix pronouns due to the addition to the end of the verbs.

At the end of this discussion, the examples of differences and characteristics of accent pronunciation of words in the Turkish language of Khorasan are cited:

1) The use of long vowel sounds like old Turkish and Turkmen is still retained in areas like Dargaz, but it has no use in other areas, for example:

Bāş 'head'

Qān 'blood'

Yāğ 'oil'

2) In some areas the letter " $k$ " at the end of the words is pronounced as " $y$ ", for example:

Çörak = Çöray 'bread'

Alak = Alay 'mesh'

Kurak = Kuray 'shoulder'

Ürak(İrak) = Üray (İray) 'heart' 
3) The rule of the harmony of the sounds in some of the regions (southern accent) is affected by Farsi and is a little downward.

4) The words that end to the final letter "- $q$ "; the "-q" letter at the end of these words sometimes is pronounced as "-x"; for example:

Qulāq = Qulāx 'ear'

5) The "māq" infinitive sign in infinitive verbs is pronounced as "māx" in some areas, for example:

Getmāq = Getmāx 'to go'

Ālmāq = Ālmā 'to buy, to get, to acquire'

6) The letter " $v$ " as the first letter of the words has turned to " $b$ " in most areas, for example:

Vermāq: Bermāq 'to give'

Vār = Bār 'there is, exists'

7) The plural sign of "lar, lār" at the time of verbs inflection to third-person plural, has turned to "lān, lan", for example:

Āldılār = Âldılān 'they bought, they got'

Vurdulār = Vurdulān 'they hit'

Getdılar = Getdılan 'they left'

Vurubdulār =Vurubdulān 'they have hit'

8) In some regions, the letter " $i$ " at the second syllable of the words has turned to "u", for example:

$$
\begin{aligned}
& \text { Āğır = Āğur 'heavy' } \\
& \text { Āçıq = Āçuq 'open' }
\end{aligned}
$$


9) In some regions, the letter " $u$ " at the second syllable of the words has turned to "I" for example:

$$
\begin{aligned}
& \text { Sut = Sit 'milk' } \\
& \text { Gun = Gin: 1) 'day' 2) 'dun, sunshine' } \\
& \text { Kul = Kil 'ash' }
\end{aligned}
$$

10) In some parts "yu" syllable, as the first letters of the word turned to "yi", for example:

$$
\text { Yumurtā = Yimirtā 'egg' }
$$

11) The letter " $z$ " at the end of the third-person singular of present negative verbs and also in some words is pronounced as " $\mathrm{s}$ ", for example:

Galmaz = Galmas 'I won't come'

Getmaz $=$ Getmas 'he won't go'

Ālmāz = Ālmās 'he/she doesn't buy, he/she doesn't get'

Qoymāz = Qoymās 'he / she won't let me'

Üz = Üs 'hundred'

Sekgız = Sekgıs 'eight'

12) In some areas the letter " $d$ " is pronounced as " $t$ ", for example:

Dāş = Tāş 'rock'

Duz $=$ Tuz 'salt'

Dolu = Tolu 'hail'

13) The letter " $b$ " as the first letter of some words turned into " $m$ ", for example:

Bunu = Munu 'this' (as an object)

Bunā = Munā 'to this'

Beyn = Meyn 'brain'

14) The letter " $c ̧$ " is also pronounced as "ş" in singular imperative verbs, for example: 


$$
\begin{aligned}
& \bar{A} c ̧=\bar{A} s ̧ \text { 'open up' } \\
& \text { Qāç = Qāç 'run, run away' }
\end{aligned}
$$

15) In some areas, the letter " $g$ " at the middle of the words, at the time of pronouncing turns to " $\mathrm{y}$ ", for example.

$$
\begin{aligned}
& \text { İgna = İna 'needle' } \\
& \text { Degmāq = Deymāq 'to be hit, to hit something' } \\
& \text { Degirmān = Deirmān 'mill' } \\
& \text { Dögmāq = Döymāq 'to grind' }
\end{aligned}
$$

16) " $r$ " in the plural suffix "lar, lār", is omitted in the words that ends to this letter, or it is pronounced shady. But at other times, when joining the other words, it is pronounced completely, for example:

Kişilar = Kişila 'men'

Ālmālār = Ālmālā 'the apples'

Ālmālārı Yu 'wash the apples'

17) The "dān 'from'" suffix is pronounced as "nān" in connection with words ending in letters $-m$ and $-n$, and in other words ending with other letters is pronounced in the original form, for example:

$$
\begin{aligned}
& \text { Sandan = Sannan 'from you' } \\
& \text { Ondān = Onnān 'from him' } \\
& \text { Qoçāndān = Qoçānnān 'from Quchan' }
\end{aligned}
$$

18) The "biz" suffix in the first person of plural of verbs in the time of now is news, as well as in some of the plural words into "miz", for example:

Galabiz=Galamiz 'we're coming'

Ālābiz=Ālāmiz 'we're buying, we're getting'

Öy biz (Öv biz) = Öy miz(Öv miz) 'our house'

Al bix = Al miz 'our hand' 
19) In regions such as Hokmabad, Joghatai, etc. the letter (ö) in the middle of the words, turns to $(E)$ and $(\ddot{U}))$ in the middle of the words, turns to (i), for example:

Çöl = Çel 'desert'

Çörak = Çerak 'bread'

Düz = Diz 'correct'

20) The existing "Qanna N" in Turkish words is still in use in some areas in the original way, for example:

$$
\begin{aligned}
& \text { Yung }=\text { Yun 'wool' } \\
& \text { Ming }=\text { Min 'thousand' } \\
& \text { Yeng }=\text { Yenı 'new' }
\end{aligned}
$$

21) In some areas, some of the word's " $d$ " are omitted in the middle of the words at the time of pronouncing, for example:

Galadılan = Galalan 'they are coming'

Ālmādu = Ālmāā 'he/she didn't buy it, didn't get it'

Odun = 1) Odın 2) Oun 'firewood'

22) In some areas, some of the extensions of "iq/uq", in the first person of verbs in simple past is pronounced as "ik (ig)", for example:

Galdıq = Galdik 'here we come'

Getdıq = Getdik 'we're gone'

$\bar{A} l d ı q=\overline{A l d i k}$ 'we bought it'

Vurduq $=$ Vurdik 'we did hit it' (Mozregi 2012)

\section{Conclusion}

As being observed, Turkish language of Khorasan has a lot of divisions. One of these accents belongs to Joghatay, where I have lived for 30 years. Unfortunately, these days 
various reasons made this accent weaker and weaker, so I believe this accent is in danger of extinction. Not only in Joghatay and subareas, but even in larger cities, Turkish accent is losing its reputation. Above all, following reasons can be among the most important one for accent loss:

1. Immigration of population, especially younger generations to the other cities to study and work, so dominant language overcame this accent.

2. Medium of instruction is Persian in all of the schools, so less exposure will happen at schools.

3. Social prestige. People are trying mostly to talking standard language and accent rather than the native one.

4. The need for communication with wider community whose language is standard one.

5. Marriage or social relationships with people of dominant language or accent.

\section{References}

CRYSTAL, David (2000) Language Death, Cambridge: Cambridge University Press.

GORDON, Raymond G., Jr. (ed.) (2005) Ethnologue: Languages of the World, 15th ed. Dallas, TX: SIL International. Online version: <http://www.ethnologue.com/>

HOFFMAN, M. (2009) Endangered Languages, Linguistics, and Culture: Researching and Reviving the Unami Language of the Lenape, (Bachelor of Arts Dissertation), Pennsylvania: Bryn Mawr College.

ISA, Z. B., K. H. AHMED \& Y. GREMA (2014) “Language Death and Endangered Languages", Journal of Humanities and Social Science (IOSR-JHSS), 11 (10), 48-68.

JongBloed, U. E. (2007) “Endangered Languages: Heritage of Humanity in Dire Need of Protection", Folios, 65-70.

LEONARD, Wesley Y. (2008) "When is an 'extinct language' not extinct?", Kendall A. King et al. (ed.), Sustaining Linguistic Diversity. Endangered and Minority Languages and Languages Varieties, Washington D.C.: Georgetown University Press, 23-33. 
LeWIS, M. Paul, Gary F. SIMONS, \& Charles D. FenNIG (eds.) (2015) Ethnologue: Languages of the World, Eighteenth edition. Dallas, Texas: SIL International. Online version: $<$ http://www.ethnologue.com/>

MAfFI, Luisa (1999) "Linguistic Diversity", in Darrell Addison Posey (Ed.), Cultural and Spiritual Values of Biodiversity: A Complementary Contribution to the Global Biodiversity Assessment, Nairobi: United Nations Environment Programme (UNEP), 21-35.

MAFFI, Luisa (2001) "Introduction", in Luisa Maffi (ed.), On biocultural diversity: Linking language, knowledge, and the environment, Washington, D.C.: Smithsonian Institution Press, 1-52.

MALONE, Elizabeth (2019) Endangered Languages. Accessed on <https://www.nsf.gov/news/special_reports/linguistics/LanguageandLinguistics/ntroductio n.pdf>

Mozregl, G. J. (2012) Ashenaee Ba Zabane Torkie Khorasani (An Introduction to Khorasani Turkish Language), Mashhad, Iran: Damineh Publication.

NETtLe, Daniel \& Suzanne RomAine (2000) Vanishing Voices, New York: Oxford University Press.

TSUNODA, T. (2001) “Language Endangerment”, in N. J. Smelser \& P. B. Baltes (eds.), International Encyclopedia of the Social and Behavioral Science, Amsterdam: Elsevier, 8349-8353.

UN (2007) United Nations Member States. Available on June 14, 2007 at the URL: <http://www.un.org/members/list.shtml>. 